\title{
"Give birth again / To the dream": Releasing the Caged Bird in Maya Angelou's Poetry
}

\author{
Dr. Abdel Mohsen Ibrahim Hashim \\ Associate Professor of English Literature, Department of English, \\ Faculty of Arts, The New Valley University, Egypt.
}

\begin{abstract}
This paper traces the journey undertaken by Maya Angelou throughout her poetry in which she struggles hard to get out of the cage and liberate herself and her African American people from the chains of an extremely bigoted white culture, bringing into sharp light the various sorts of injustice and oppression practiced against black people in American society. For the theoretical framework of this paper, the researcher primarily draws on the history of slavery and racism in the United States as well as the history of the Civil Rights Movement in which Angelou played a significant role. Then, examples of Angelou's poems revealing racial segregation, inequality, and discrimination against black Americans are thematically and technically analyzed. Angelou, the researcher sees, adopts certain strategies and mechanisms in order to set the caged bird free and help the oppressed in her poetry throw away their heavy burden of suffering which they have long endured in a racially oppressive society. Instances of the poems conveying these meanings are given and elucidated, together with a concluding note of hope and happiness running through Angelou's poetry, particularly after her success in rising above bigotry and narrow-mindedness.
\end{abstract}

Keywords: Caged Bird, releasing, Maya Angelou, poetry

... a bird that stalks

down his narrow cage

can seldom see through

his bars of rage

his wings are clipped and

his feet are tied

so he opens his throat to sing.

— (Angelou, Shaker, Why Don't You Sing? 16)

Maya Angelou, in her famous poem 'Caged Bird' which is quoted above, associates herself with the trapped bird who 'opens his throat to sing' in an attempt to break free from 'his narrow cage' though 'his wings are clipped and / his feet are tied'. According to Angelou, the route to freedom and equality is always surrounded by difficulties and those who seek a release out of the cage that confines their free will 
and restricts their love for life have to face lots of losses and defeats till they can finally achieve the dream they yearn for. This was the case of Angelou and her fellow African Americans who had to overcome terrible hardships and endure great suffering in order to find a voice and create an existence within the restraints of a highly discriminatory system.

Martin Luther King, in his memorable speech delivered in 'The March on Washington' demonstration that he led in 1963, expressed the dream he had that day when he said, "I have a dream that my four little children will one day live in a nation where they will not be judged by the color of their skin but by the content of their character" (qtd. in Friedman 45). For Angelou, King's dream that African American people live in a nation founded on the principles of justice and equality can come true as long as people in society deal with each other according to a code of ethics that makes them respect each other and provides them with hope to have a better life. This is what Angelou asserts in her well-known poem, 'On the Pulse of Morning', which was recited by the poet at President Clinton's first inauguration in 1993. Angelou optimistically urges black people who aspire to getting out of the cage of racism to defend their noble cause and work hard till their dream of freedom turns into reality. Addressing people who have such a dream, the poet states:

\section{Lift up your eyes}

Upon this day breaking for you.

Give birth again

To the dream. (On the Pulse of Morning 13)

Hailed by critics and politicians as one of the most influential Civil Rights Activists and defenders of the rights of blacks, Angelou was awarded the Presidential Medal of Freedom--America's highest civilian honor--by President Barack Obama in 2011. As a poet, memoirist, dramatist, novelist, educator, historian, filmmaker and actress, she is an eminent figure whose works vividly reflect the black experience and honestly reveal the misery endured by the oppressed in the United States. 
Dating back to the early beginnings of settlement in the continent, slavery and racism form a dark chapter in American history. According to Amy Kass and Leon Kass, "The system of chattel slavery that took hold in the Americas within a year of Christopher Columbus's landing perpetually enslaved Africans, deprived them of basic human rights and created an entrenched racial hierarchy" (6). Michèle Duchet points out that it was the Spaniards who first took blacks to the New World in the early years of the fifteenth century and exploited them there as slaves (31). In those years, Spain wanted to provide manpower to its colonies in America. More importantly, it was widely proclaimed that "Africans, in general, were intellectually inferior to Europeans, that Negroes, using the expression of those days, stood closer in the line of development to apes than to human beings. This was the beginning of racism in regard to Africans" (Abramova 23-24).

When Europeans settled in America and had colonies there, they looked at blacks as savage and barbarian people who needed to be refined and become more civilized. Therefore, they imposed their European culture and Christian religion on all the inhabitants of their American colonies and practiced all kinds of racial oppression against them. In general, slaves were badly treated, and their human rights were severely violated; their mistreatment not only included physical violence, but it also took many other forms such as economic deprivation, social marginalization, brutal rape and sexual abuse of women.

Yearning for breaking free from the racial cage that subjugated them and snatched dignity out of their lives, black Americans decided to resist and defy that suppressive system through organizing bold rebellions against their white oppressors. Accordingly, many revolts were organized and "by 1822," Stephen Kynor indicates, "over 150 slave revolts or attempted slave revolts had taken place in the United States" (55). In a glimpse of hope for blacks, President Abraham Lincoln signed the 1863 Emancipation Proclamation according to which black slaves in the United States turned legally into free people. Nevertheless, black Americans were deprived of most of their rights. Put another way, white supremacy insisted on keeping the African Americans socially marginalized, economically weak, politically powerless, and culturally uneducated. Despite all promises of freedom, blacks were still unable to get 
out of the cage as racial oppression and inequality were still widely practiced against them.

To add to the degradation of black people, the Supreme Court approved Jim Crow laws in 1896. According to those laws, the African Americans were forced to use separate facilities and services which were not in fact equal to those given to white citizens. These were the conditions of black people in America, the country that was founded on the principle that "all men are created equal," states Sara Bullard satirically, asking us to

Imagine being unable to eat or sleep in most restaurants or hotels; being unable to sit where you wanted in a movie theater; having to sit in the back when you boarded a bus, even an empty one; being forced to attend an inferior school; and even being forbidden to drink from certain water fountains. These were the facts of everyday life for all black people in the Southern part of the United States as recently as1960. (10)

These 'separate but equal laws', as they were often referred to, were met with full rejection by all African Americans who were determinant to resist them whatever price they might pay. Therefore, they began to found various organizations to resist injustice and oppose segregation. Prominent among these organizations was the National Association for the Advancement of Colored People (NAACP) that was established in 1909 in order to defend the civil rights of black people. Leaders and members of the NAACP had a strong belief that "the Constitution, if properly applied, would grant African Americans equality" (Woodley16). The association grew up very rapidly and could remarkably find itself a distinctive place on the political stage of the United States.

A great achievement of the NAACP is its success to prove, through its lawyers, that Jim Crow laws had indeed violated the rights of blacks in American society, something which made the Supreme Court nullify them on the seventeenth of May, 1954 on the basis that, to quote Amy Kass and Leon Kass, "the guiding principle of segregation-separate but equal-was unconstitutional"(8). This legal triumph which the NAACP had effectively accomplished was one of two basic 
incidents in the 1950s that "brought the issue of civil rights squarely into the public spotlight" (Karson 13). The other significant incident happened on the first of December, 1955 when Rosa Parks, a black activist belonging to the NAACP, insisted not to abandon her seat in the section specified for blacks at the end of a public bus for a white passenger after the white section at the front was full. Parks was soon arrested, and the incident moved the enthusiasm of African American people who found in it an excellent chance to protest against racial segregation and expose the unfair standards governing life in American society during that time. Out of these two incidents, and of other similar examples of racial discrimination, the Civil Rights Movement in the United States was born.

The years from 1955 to 1960 witnessed a remarkable success for the African American activists as they could strongly attract public attention to their cause. In 1957, the first Civil Rights Act was passed by Congress to outlaw attempts that had threatened or prevented blacks from practicing their right to vote. The Civil Rights Movement was enriched by the formation of new organizations whose members, like those of the NAACP, took upon their shoulders the call for equal civil rights. For example, the Southern Christian Leadership Conference (SCLC) that was founded in 1957 and led by Martin Luther King, and the Student Nonviolent Coordinating Committee (SNCC) which was established in 1960 by black university students "grabbed the media spotlight," to quote Jill Karson, "bringing black demands before the public eye as never before" (15).

The continued victories achieved by the Civil Rights Movement against racial oppression and injustice fueled the American scene and reached the White House itself where a strong tendency for reform was rapidly increasing. This was reflected by President John F. Kennedy's Civil Rights Address to the American people on the eleventh of June, 1963 in which he affirmed that an obligation was to be maintained by the government that "race has no place in American life or law" (qtd. in McInerney and Israel 272). Perhaps the greatest happening throughout the Civil Rights Movement history took place on August 28, 1963 when Martin Luther King led a huge demonstration of black and white people in front of the Lincoln Memorial in what was known as the March on Washington. In that demonstration, King delivered his memorable 'I Have a Dream' speech to assert the protesters' quest for justice and 
equality. The incident stands as the largest political demonstration America had ever seen.

It is worth mentioning that Angelou played an active role in the Civil Rights Movement. Not only did her articles and books against racial discrimination and oppression attract attention to her as an influential political voice, but she was also a part of the Civil Rights struggle itself. She was very enthusiastic to work with famous black activists such Martin Luther King and Malcolm X. When Angelou met King, she was highly inspired by his powerful speech and heroic actions. Eagerly, she began to think of a way to support the civil rights organizations; she started with raising funds to sustain the Southern Christian Leadership Conference (SCLC) through organizing the Cabaret for Freedom benefit. In 1959, she was asked by King to become the northern coordinator for the SCLC and she felt happy to accept such an important position through which she had the chance to work side by side with that eminent black leader who had a great influence on her political development.

In 1960, Angelou travelled to Egypt to serve as the editor of the Arab Observer, a weekly news magazine in English issued from Cairo. A leading member of the Non-Aligned Movement that was founded in 1961, Egypt at that time was led by President Gamal Abdel Nasser who turned the country into a well-known center supporting anti-colonial movements that protested against imperialism and its racial attitudes (Azikiwe). In 1964, Angelou left Egypt and went to Ghana where she worked as the editor of the African Review in Accra. Her stay in the Ghanaian capital gave her the opportunity to meet Malcolm X who visited Accra in 1964. Admiring the young man's courageous defense of blacks' rights, Angelou decided to return later to the United States to support him with his new Organization of Afro-American Unity (OAAU), but unfortunately he was assassinated in 1965. Lamenting the death of Malcolm X, Angelou writes her poem,' To a Freedom Fighter', in which she shows how the brave young man has readily sacrificed himself and willingly chosen to 'die a thousands' death' for the sake of providing blacks in America with the freedom they have long dreamt of:

You drink a bitter draught.

I sip the tears your eyes fight to hold,

A cup of lees, of henbane steeped in chaff. 
Your breast is hot,

Your anger black and cold,

Through evening's rest, you dream,

I hear the moans, you die a thousands' death.

When cane straps flog the body

dark and lean, you feel the blow.

I hear it in your breath. (Poems 35)

Throughout her poetry, Angelou depicts African American people as yearning for freedom and self-assertion. They dream of being released out of the cage of racism but the miserable life they lead and the unbearable hardships they face kill hope in their souls and make them see all their 'days' as miserable and gloomy. This meaning is embodied in Angelou's 'The Memory', a poem whose title is very significant suggesting that the depressing conditions raised by the narrator in the lines are powerfully carved in 'the memory' of all blacks who cannot forget the pains of confinement and the hopes for liberation. In the poem, the black speaker bitterly moans telling us how

Cotton rows crisscross the world

And dead-tired nights of yearning

Thunderbolts on leather strops

And all my body burning

Sugar cane reach up to God

And every baby crying

Shame the blanket of my night

And all my days are dying

(Poems 151)

The above lines reveal the depressing conditions of black people and the wretched life they lead. The 'cotton rows', the 'dead-tired nights' and the 'thunderbolts on leather strops' are all phrases that deepen the speaker's sense of humiliation and 'shame' caused by slavery that hurts his pride and wounds his self-esteem. Remarkably, the whole poem is read as an enjambment; this implies that the speaker is so frustrated 
that he wishes to utter all his speech in one breath so that he can throw away all what makes him sad and miserable; perhaps, one imagines, this action relieves his distressed heart and brings ease to his exhausted soul. It is not only the lines throughout the poem that are read without any interruption by punctuation, but even the end of the poem is not marked by a period or any other punctuation mark, as if the poet attempts to convey the meaning that the deep cry of the depressed speaker is nonstop and still heard all over the ages. In addition, the poet's use of the gerund form in 'burning', 'crying' and 'dying' reflects the continuity of suffering endured by African-American people throughout their quest for freedom and human dignity. The rows of cotton fields, where the black slaves work on, 'crisscross the world' imprisoning them in a frustrating environment out of which they find no escape. The result is that their bodies are 'burning', possibly due to the heat of the sun or because of the pain of being tied to such a disappointing circle of life; they are also 'crying' and groaning endlessly because of their tragic fate as slaves who are slowly 'dying' every day.

In a note of hope, the 'sugar cane reach up to God', carrying with them blacks' aspirations for liberty and equality. However, even that wish for free will and justice is strangled by the bitter reality in which the 'days' of the powerless speaker are 'dying'. Notably, there is an example of alliteration in the two words 'days' and 'dying' as the consonant /d/ comes at the beginning of both words, therefore connecting them together and suggesting that blacks' lives are fading and their 'days' are 'dying" and being spent in vain.

The memory of slavery and its effects on black Americans are further investigated in 'My Guilt', a poem in which Angelou, speaking in the first person singular pronoun, feels remorseful whenever this memory knocks at the door of her mind. This sense of sorrow and regret is represented on three levels: 'guilt', 'crime', and 'sin'. Throughout the poem, each of these words is preceded by the possessive pronoun 'my' as if Angelou likes to assert that these feelings which hurt the heart and wound the soul are her own; the narrator feels the heavy burden of remorse at slavery and its consequences on African-American people, particularly the great black activists and freedom defenders who had sacrificed themselves and their families and had paid their lives as a price for attaining the human dignity and self-assertion which all blacks in the United States enjoyed later. The three levels of meaning ('guilt', 
'crime', and 'sin) are expressed by the three stanzas of the poem where each stanza is devoted to one level. The first stanza deals with the sense of 'guilt' as a main topic. Angelou writes:

$$
\begin{aligned}
& \text { My guilt is “slavery's chains," too long } \\
& \text { the clang of iron falls down the years. } \\
& \text { This brother's sold, this sister's gone, } \\
& \text { is bitter wax, lining my ears. } \\
& \text { My guilt made music with the tears. }
\end{aligned}
$$

(Just Give Me a Cool Drink 42)

The narrator feels guilty at remembering the 'long' history of slavery and racism in America and how African-American slaves suffered 'too' much and nevertheless were able to resist and face all kinds of injustice and hardship. Remorsefully, Angelou recalls the bad effects of living in a highly discriminatory society like the American one where black people were tightly caged by the 'chains' of 'slavery' and racial oppression. Black slaves had to endure the pain of racism which captivated them, split up their families, and kept them suffering 'the clang of iron' falling 'down the years'.

In the second stanza, the feeling of guilt develops inside the speaker into a more complicated emotion turning into a sense of committing a 'crime'. This is what the poet sorrowfully asserts:

$$
\begin{aligned}
& \text { My crime is "heroes, dead and gone," } \\
& \text { dead Vesey, Turner, Gabriel, } \\
& \text { dead Malcolm, Marcus, Martin King } \\
& \text { They fought too hard, they loved too well. } \\
& \text { My crime is I'm alive to tell. }
\end{aligned}
$$

(Just Give Me a Cool Drink 42)

The narrator's 'crime', Angelou explains, lies in remembering the black 'heroes' of the past who embraced death in order to shape a better future for all blacks in the United States. Of these were the first leaders of slave rebellions in America such as Denmark 
Vesey (1767-1822), Nat Turner (1800-1831), and Gabriel Prosser ((1776-1800), and the pioneers of the new generation of civil rights activists who came later and 'fought too hard' for the cause of black people such as Malcolm X (1925-1965), Marcus Garvey (1887-1940), and Martin Luther King (1929-1968). These brave 'heroes' who are now 'dead and gone' 'fought too hard' for the liberation of all blacks and 'loved' their people and their cause 'too well'. At the last line of the stanza, the narrator points out that her 'crime' is that she is still 'alive to tell' the glorious stories and heroic deeds of those noble men; this, of course, deepens her sense of remorse and complicates her mission as a narrator because she now realizes very well how expensive the cost of freedom was. Blacks could not have become free unless those great heroes had sacrificed themselves as a cost for liberty. What adds to her feeling of regret and intensifies her 'crime', from her point of view, is that she survived while the creators of liberty themselves had died in the course of struggle against slavery and racism. This is exactly what makes the speaker feel sorry and remorseful as if she is shy to receive her present freedom or incapable of enjoying the grace of liberty provided for her.

The last stanza of Angelou's 'My Guilt' depicts the final level of the development of the narrator's sense of guilt which has turned in the second stanza into 'crime' and now progresses into 'sin'. As the poet states:

My sin is "hanging from a tree,"

I do not scream, it makes me proud.

I take to dying like a man.

I do it to impress the crowd.

My sin lies in not screaming loud.

(Just Give Me a Cool Drink 42)

Vividly, Angelou compares the struggle against racial oppression to the act of lynching. Comparing herself with the greater black heroes and protesters, the speaker feels sinful because she sees that her pride prevented her from 'screaming', that is, from taking part in the fight against discrimination and injustice. The narrator preferred, the poet indicates, impressing 'the crowd' to asserting herself and dying for 
the sake of her cause as a black person. Her sin is embodied in her inability to scream 'loud' and sacrifice her life for the sake of her fellow blacks.

In the poem, Angelou uses her poetic techniques to reflect her sense of remorse. It is noted that the poem consists of three stanzas, five lines each. The first line and the last line of each stanza start with the same phrase referring to the main theme of the stanza: My guilt (stanza1), My crime (stanza 2), and 'My sin' (stanza 3). This implies that the narrator does confess her feeling and never denies it. In addition, one feels that the repetition of the phrase denoting the speaker's emotion at the beginning and end of the stanza gives coherence to the lines, encloses the whole stanza with the dominant idea raised by the poet, and helps convey the intended meaning to the reader.

The poet cleverly ends each of the three stanzas of the poem with a rhyming couplet that summarizes the whole stanza and reflects the feeling of the speaker. For example, the rhyme between 'ears' and 'tears 'in the first stanza connects the two words together and reveals how the effects of slavery such as the captivity or separation of the brothers and sisters makes the speakers' ears become lined 'with 'bitter wax' when she receives these tragic news, and as a result her 'tears' spontaneously gather in her eyes and rise in her heart deepening her sense of guilt. Very indicative is the poet's depiction of her sense of 'guilt' which expressively 'made music' in tune with the falling tears. Similarly, the rhyme between 'well' and 'tell' in the concluding couplet of the second stanza is suggestive; it implies that the freedom fighters of the past achieved their tasks of fight and love 'too hard' and 'too well' that the speaker feels remorseful as if she has committed a 'crime' because she survived these heroic actions and their noble doers, and had to 'tell' these events to other generations. Within the same context, the rhyme between 'crowd' and 'loud' in the last two lines of the third stanza reflects the speaker's sense of 'sin' as a result of her choice 'to impress the crowd' and not to shout 'loud' as a sign of dying courageously in the fight against racism.

Angelou's poetry honestly reveals the dilemma of the African American people who have to confront exploitation and subjugation on a daily basis. 'Why Are They Happy People?' is a poem which shows how the white masters oppress the 
helpless slaves, humiliate them, and practice all sorts of dictatorship against them. The title is really evocative, indicating that the fully dominated African Americans are not happy at all; rather, they are desperate people who are compelled to survive and cope with their harsh conditions of living, even if their life is awful and unbearable. Amidst their plight and misery, these powerless blacks are asked by their white masters to play the role of 'happy people'. As Angelou clarifies in the poem, the white oppressors tyrannically direct orders to their victims as follows:

Skin back your teeth, damn you,

wiggle your ears,

laugh while the years

race

down your face.

Pull up your cheeks, black boy,

wrinkle your nose,

grin as your toes

spade

up your grave.

Roll those big eyes, black gal,

rubber your knees,

smile when the trees

bend

with your kin. (I Shall Not Be Moved 17)

Remarkably, the poet uses the imperative form ('skin back', 'wiggle', 'laugh', 'pull up', 'wrinkle', 'grin', 'roll', 'rubber', and 'smile') to convey the monocracy of the white people who mercilessly exploit their slaves forcing them to pretend to be happy at the time when they, the slaves, helplessly groan and slowly move into death. These wretched creatures are cursed, belittled, ridiculed, insulted and, above all, obligated by their white tormentors to 'laugh' while they are defeated and 'smile' while they dig their own 'grave'. Throughout the poem, apostrophe is employed by the poet to emphasize the idea raised in the lines and to reflect how the oppressors use their authoritarianism against the oppressed. The two expressions, 'damn you' in line one 
and 'black boy' in line six, summarize the whole poem as they reveal how blacks are damned and exploited in the racially prejudiced American society.

In such a domineering white culture that represses black Americans and kills life in them, Angelou's poetry comes to announce the absence of 'equality' and expose "American myths that promise justice for all but only guarantee freedom for a few" (Neubauer 132). 'Equality' is a poem in which Angelou, as a spokesperson for the African American race, speaks for the unheard who struggle to find a voice and dream to be treated equally regardless of their origin, skin colour, or social status. Addressing an unmoving white society that is unfeeling and unconcerned about the pains of those who suffer, the poet cries out:

Take the blinders from your vision,

Take the padding from your ears,

And confess you've heard me crying,

And admit you've seen my tears.

Equality, and I will be free.

Equality, and I will be free.

\section{(I Shall Not Be Moved 12)}

In an accusing manner, the poet asks white people to 'admit' their deliberate blindness to the wounds they have caused for the oppressed. These uncaring and indifferent whites, the poet requests, should open their eyes, remove what blocks their 'ears' and 'confess' that they have already seen the heavy 'tears' and heard the bitter 'cries' of the African Americans who are neglected and mistreated by an oblivious white society marked by its intended wrongdoings and discriminating attitudes against the subjugated. Having urged the white oppressors to take action and meditate on the crimes they have committed against helpless blacks in American society, the speaker now calls for 'equality' as the most effective remedy and the best guarantee that the oppressed will be released from the racial cage and get the freedom they have long looked for. To be equal means to be free; this is the essence of the poem and the message Angelou raises in the lines. 
Skillfully, the poet uses both punctuation and repetition as technical devices that reflect her thoughts and convey her feelings. The poem ends with the repeated line 'Equality, and I will be free'. Punctuation here is used in a very expressive way. That the line ends with a period suggests that what the poet has mentioned in the line is all what she wants; if she is given equality only, she will get her freedom. She does not need more than this to make her dream of liberation come true. Additionally, the repetition of the line emphasizes the speaker's idea that she and other oppressed victims cannot be liberated unless 'equality' governs life in American society. Also, repetition here reflects the speaker's insistence and determination to break 'free' from the cage of that suppressive culture which inhumanly insults people of colour and intentionally ignores their suffering.

Angelou is best known for her masterpiece I Know Why the Caged Bird Sings, an autobiography that highlights young Maya's struggle for freedom and personal identity in a racially repressive environment. Throughout the book, Angelou tells her readers how American society is extremely marked with racism and prejudice against African American people. If this autobiographical work realistically displays the reasons and conditions which make the caged bird rise up and sing in search of liberty, Angelou's poetry--in addition to its vivid portrayal of the various types of oppression endured by the enslaved bird--amazingly embodies the release of that bird out of the cage that has long restricted his freedom and hindered his love for life. 'Caged Bird' is one of the most expressive poems written by Angelou to reflect this meaning. Consisting of six stanzas, the poem portrays the trapped bird's yearning for liberty and traces the attempts the bird makes to break free from the captivity 'bars' that have 'clipped' his wings and 'tied' his feet. The locked up bird symbolizes Angelou herself and the other oppressed African Americans who are imprisoned in the cage of racism and discrimination.

Stanzas 1 and 2 of the poem contrast the bird that is caged and isolated with his counterpart that is free and happy, Angelou writes:

\footnotetext{
A free bird leaps

on the back of the wind

and floats downstream
} 
till the current ends

and dips his wing

in the orange sun rays

and dares to claim the sky.

\author{
But a bird that stalks \\ down his narrow cage \\ can seldom see through \\ his bars of rage \\ his wings are clipped and \\ his feet are tied \\ so he opens his throat to sing.
}

(Shaker, Why Don't You Sing? 16)

Full of joy and energy, the free bird ecstatically celebrates his freedom and positively interacts with nature and its elements as he 'leaps' here and there and 'floats downstream' till he reaches the ends of the water current. He also plunges his wing in the beautiful, coloured 'rays' of the 'sun' as a sign of delight and cheerfulness. The happy bird boldly claims the sky and confidently asserts his free will. In contrast, the 'caged bird' is deprived of the blessings which the free bird enjoys. Instead of jumping blissfully 'on the back of the wind' as the free bird does, the enslaved bird only moves up and down 'his narrow cage', unable to get out and reach the outside world which is separated from him by the strong bars of imprisonment. Despite all these obstacles and despite his awareness that 'his wings are clipped 'and 'his feet are tied', the 'caged bird' does not give up his endevour for getting out of the cage; he finally 'opens his throat to sing' in search of freedom and self-assertion.

Outstandingly, Angelou uses diction as a technical device that conveys her feelings and reflects her ideas. The choice of verbs like 'leaps', 'floats', 'dips', 'dares', and 'claims' reveals the sense of happiness, liveliness, self-determination and enthusiasm from the side of the free bird to embrace nature and celebrate his liberty. Furthermore, the words 'wind', 'downstream', sun' and 'sky' are suggestive as they expressively reveal the beautiful natural setting where the excited bird composes his 
symphony of love and freedom. Contrasted with these words that denote delight and joyfulness in the first stanza, the words 'cage', 'seldom', 'bars', 'rage', 'clipped' and 'tied' in the second stanza reflect the feelings of entrapment, oppression, helplessness, and the inability of those who are caged and captive to interact with the beauty life offers outside the cage. In spite of the gloomy picture which these words draw, the use of the word 'sing' at the end of the stanza conveys hope and maintains that the caged bird, though restricted by captivity and the 'bars of rage' which he has to endure together with his 'clipped wings' and 'tied feet', can still open' his throat to sing' of freedom and life.

The third stanza focuses on the caged bird's song itself, handling it with more examination and interpretation. The caged bird sings, producing quavering or trembling sounds that reveal his fear and reflect his plight. The powerless bird has the desire to express his longing for freedom but this desire is hindered by his helplessness and failure to break away from confinement and oppression. Nevertheless, he 'sings', "gives 'birth again / To the dream," to quote Angelou's On the Pulse of Morning (13), and his singing voice is heard all over the place. His thirst for liberty never stops. Significantly, Angelou insists throughout the poem that it is the caged bird, and not the free one, that always 'opens his throat' and sings of freedom as if she hints that it is the oppressed who really lack the sense of being free and therefore sing, seeking a release out of the cage .

The fourth and fifth stanzas continue the sharp contrast between the free bird and the caged bird. The poet points out how the free bird celebrates his freedom and enjoys the beauty of nature represented by the pleasant breeze, the soft winds that are softly produced by "the sighing trees", and "the fat worms" that contentedly wait on the beautiful grass in full serenity during the magnificent time of "dawn" (Shaker, Why Don't You Sing? 16). Not only does the free bird enjoy his liberty to the full, but he also embraces the sky very happily, and daringly calls it his own. On the contrary, the caged bird--with his 'wings' still 'clipped' and his 'feet' still 'tied'--sadly dreams to break the chains of cage and get rid of the nightmare of imprisonment. He still hopes to get released and become free.

The last stanza of "Caged Bird" is a literal repetition of stanza three which concentrates on the song of the caged bird. Angelou in this stanza employs the 
technique of repetition in order to emphasize her theme and stress the idea she poses. Despite the fact that the caged bird is locked up in its cage, the poet reminds us, his heart still beats with life and hopes to be set free. The message of the poet in this stanza in particular and in the poem in general is obvious: no despair continues forever, and no cage can confine the yearning for liberty. It is true that the caged bird is captive, but he can still have the ability and strength of will to open 'his throat' and sing till he gets the freedom which he and all the oppressed seek to attain.

Remarkably, Angelou uses the run on line technique in all the stanzas of the poem from the first line up to the last one of each stanza. Employing this technical device, the poet stresses the idea that each of the two birds, the free and the caged, is continuously reacting to his status quo. The free bird keeps on enjoying life very happily in order to assert the liberty he has got. Likewise, the caged bird goes on singing to affirm that he is keen to get released out of the cage that restricts his freedom.

It is worth noting that 'Caged Bird' was inspired to Angelou by 'Sympathy', a poem written by the African American poet and novelist Paul Laurence Dunbar. However, there is an essential difference between Dunbar's caged bird and Angelou's. While the caged bird in Dunbar's poem "sings from the frustration of imprisonment [and] its song is a prayer," writes Myra McMurry, "Angelou's caged bird sings also from frustration, but in doing so discovers [that] the song transforms the cage from a prison that denies selfhood to a vehicle for self-realization" (106).

In her poetry, Angelou adopts a number of strategies in order to release the imprisoned bird out of the cage. One of these strategies is rising up and singing of freedom, as seen above in the poem 'Caged Bird'. Another strategy used by the poet to reach the safe shores of liberty is adhering to hope and determination. Addressing the white oppressor, the poet determinedly declares,

You may shoot me with your words,

You may cut me with your eyes,

You may kill me with your hatefulness,

But still, like air, I'll rise.

(Collected Poems 163) 
Identifying with African heritage and the ancestors' history is the third strategy Angelou resorts to in order to liberate herself and her black people from the cage of racism. Proudly, the poet maintains that adherence to her African roots is what really provides her with strength and enables her to reach the stance of a free bird:

Up from a past that's rooted in pain

I rise

I'm a black ocean, leaping and wide,

Welling and swelling I bear in the tide.

Bringing the gifts that my ancestors gave,

I am the dream and the hope of the slave.

I rise

I rise.

I rise.

(Collected Poems 164)

After singing of freedom, sticking to hope and determination, and asserting her African belonging, Angelou comes now to summon on love as the last and most comprehensive strategy in her quest for liberation. According to the poet, love immediately responds to the call of the oppressed, arrives on time from 'its high holy temple' and 'sets' all caged birds 'free'. This is what the poet indicates in 'Touched By An Angel', a poem in which Angelou tells her readers that she and her fellow African Americans have led a miserable life and suffered much suppression and inequality

until love leaves its high holy temple

and comes into our sight

to liberate us into life.

love strikes away the chains of fear

from our souls.

In the flush of love's light

we dare be brave 
$\ldots$ it is only love

which sets us free.

(qtd. in Reder 194)

As a divine power, love comes to release the subjugated from all forms of injustice and discrimination. To achieve its mission, love takes certain steps. First, it 'strikes away the chains of fear from the 'souls' of these enslaved people; then, it teaches them to 'dare be brave'; and finally, it provides them with freedom, their long-sought dream. Impressively, Angelou shows how love

... rose into my life

Like a promised sunrise.

Brightening my days with the light...

I've never been so strong,

Now I'm where I belong.

(The Complete Poetry 125)

Having successfully ended her journey from a caged bird to a free self, Angelou comes to celebrate her great accomplishment and present her eternal song of life and liberty. Daringly, she has had the ability to defeat the racism of a domineering white culture that has long enslaved black people and assassinated their aspirations for justice and human dignity. Through the vehicle of her poetry, she has metaphorically liberated those who have suffered victimization and has safely taken them to the harbors of freedom, happiness, and self-realization. Angelou, who stands for all black Americans and for the oppressed everywhere, gives her final words asserting that the hard times of 'fear' and repression have been forgotten and a new stage of hope and satisfaction is to start:

Leaving behind nights of terror and fear

I rise

Into a daybreak that's wondrously clear

I rise.

(Collected Poems 164) 


\section{Works Cited}

Abramova, S. U. "Ideological, Doctrinal, Philosophical, Religious and Political Aspects of the African Slave Trade." The African Slave Trade from the Fifteenth to the Nineteenth Century. Reports and Papers of the Meeting of Experts, Organized by UNESCO at Port-au-Prince, Haiti, 31 January to 4 February, 1978. UNESCO, 1979. pp. 16-30.

Angelou, Maya. I Know Why the Caged Bird Sings. Random House, 2009.

---. I Shall Not Be Moved. Random House , 1990.

---. Just Give Me a Cool Drink of Water fore I Diiie. Random House, 1971.

---. Maya Angelou: The Complete Poetry. Random House, 2015.

---. On the Pulse of Morning. Random House, 1993.

---. Poems. Bantam, 1986.

---. Shaker, Why Don't You Sing? Random House, 1983.

---. The Complete Collected Poems of Maya Angelou, 1st ed., Random House, 1994.

Azikiwe, Abayomi. "Maya Angelou Gave Literary, Political Voice to AfricanAmerican Women." Workers World, 3 June 2014, www.workers.org/2014/06/03/maya-angelou-gave-literary-political-voiceafrican-american-women/. Accessed 27 Oct. 2018.

Bullard, Sara, editor. Free at Last. A History of the Civil Rights Movement and Those Who Died in the Struggle. Southern Poverty Law Center, 1993.

Duchet, Michèle. "Reactions to the Problem of the Slave Trade: An Historical and Ideological Study." The African Slave Trade from the Fifteenth to the Nineteenth Century. Reports and Papers of the Meeting of Experts, Organized by UNESCO at Port-au-Prince, Haiti, 31 January to 4 February, 1978. UNESCO, 1979. pp. 31-54.

Friedman, Michael Jay, editor. Free at Last: The U.S. Civil Rights Movement. U.S. Department of State, Bureau of International Information Programs, 2008. Karson, Jill . "Introduction." The Civil Rights Movement. Edited by Jill Karson. Thomson Gale, 2005. pp. 11-20.

Kass, Amy A., and Leon R. Kass, editors. The Meaning of Martin Luther King Jr. Day. What So Proudly We Hail. Org, 2013.

Kynor, Stephen Michael. "The Moses of Charleston: Denmark Vesey." 
Undergraduate Research Journal. University of Colorado at Colorado Springs (UCCS), vol. 10. no.1, 2016. pp. 54-68.

McInerney, Thomas J., and Fred L. Israel, editors. Presidential Documents: The Speeches, Proclamations, and Politics That Have Shaped the Nation from Washington to Clinton. Routledge, 2013.

McMurry, Myra K. "Role-Playing as Art in Maya Angelou's 'Caged Bird'." South Atlantic Bulletin, vol. 41, no. 2, 1976. pp 106-111.

Neubauer, Carol E. "Maya Angelou: Self and a Song of Freedom in the Southern Tradition." Southern Women Writers: The New Generation. Edited by Tonette Bond Inge. The University of Alabama Press, 1990. pp. 114-142.

Reder. Estelle R. That's My Story, Book 1 - Taking a Courageous Path. Strategic Book Publishing and Rights Co. 2009.

Woodley, Jenny. "In Harlem and Hollywood: The NAACP's Cultural Campaigns, 1910-1950." Long Is the Way and Hard: One Hundred Years of the NAACP. Kevern Verney and Lee Sartain, editors. University of Arkansas Press, 2009. pp.15-28. 


\section{"اطلق العنان للطلم تارةً أخرى": إطلاق سراح الطائر الحبيس في شعر مايا أنجيلو}

د. عبد المحسن إبر اهم هانشم، أستاذ مشارك الأدب الإنجليزي- قسم اللغة الإنجليزية كلية الآداب - جامعة الو ادي الجديد، مصر .

المستخلص:

ترمي هذه المقالة إلى تتبع الرحلة التي تقوم بها الثناعرة مايا أنجلو عبر قصائدها الثعرية والتي تحاول فيها جاهدةً أن تحرر نفسها وبني شعبها، أولئك الأمريكيين الأفارقة، من الاضطهاد الذي يمارسه ضدهم الأمريكيون البيض في مجتمع ظالم يتخذ من التمييز العرقي أساساً لتعاملات افراده. ويعتمد الباحث في الإطار النظري لهذه الدراسة على إلقاء الضوء على تاريخ العبودية والعنصرية في أمريكا، وكذللك حركة الحقوق المدنية والتي لعبت فيها أنجلو دوراً هاماً. يقوم الباحث بعد ذلك بدراسة تحليلية لأمثلة من قصائد أنجلو الني تكثف عن الظلم والقمع والفصل العنصري الذي طالما عانى منه الأمريكيون السود وتجرعوا مرارته. ومن الجدير بالذكر أن الثاعرة تضع دأن لنفسها مجموعة من الاستراتيجيات والآليات تستطيع من خلالها إطلاق سراح الطائر الحبيس في شعرها وتمكين المضطهدين من نفض غبار الظلم والقهر والعنف والاستغلال الذي مارسته ضدهم نقافة عنصرية متعسفة تبناها الكثير من الأمريكيين البيض وأعلو لواءها. ويعرض الباحث لمجموعة من القصائد التي توضح هذا المعنى في وني

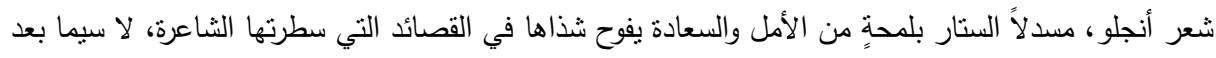
نجاحها في التغلب على العنصرية والتعسف وضيف الأفق. الكلمات الدلالية: الطائر الحبيس، إطلاق سراح، ، شعر، مايا أنجيلو 